\title{
sciendo
}

\section{The Basketball Pass: A Systematic Review}

\author{
by \\ Arturo Quílez Maimón¹, Javier Courel-Ibáñez², Francisco Javier Rojas Ruíz ${ }^{1}$
}

\begin{abstract}
The aim of this study was to review and organise current literature about the basketball pass and find the main factors that influence its learning skills and performance. Thirty-seven studies were included after the screening process. The documents were classified into main research topics. This review identified the following conclusions: (i) the assessment of passing performance should be made under uncertain and variable conditions to obtain information on players' responses to competitive scenarios, (ii) it is advisable to incorporate new and random activities to facilitate the transference of learning to the competition, (iii) it is recommended to include overwhelming factors during the practice to minimise the effect of pressure and choking, (iv) optimal physical conditioning is essential to maintain passing performance during a basketball game, (v) small sided games and changing environments stand as the best training situations to improve passing skills. Furthermore, limited information is available about biomechanical aspects and physical conditioning training programs to improve passing skills in basketball. Likewise, there is sparse data on passing skills development in children.
\end{abstract}

Key words: team sports, technique, tactics, learning, skills.

\section{Introduction}

The basketball pass is the most basic collective interaction and, after shooting, it constitutes the second most common technical action used in the game (Nunes et al., 2016). During the offence, players are required to keep the possession of the ball and cooperate to create optimal shooting options to increase effectiveness. Teams that assist more (i.e., give a pass that leads to a score) are more likely to win the game (García et al., 2013; Gomez et al., 2013). On the other hand, reductions in turnovers (i.e., lost possession) increase the winning odds, particularly in close games (Ribeiro and Sampaio, 2001). According to Gómez et al. (2009) the pass error/success ratio is the main distinguishing factor between starters and non-starters in elite competitions. Therefore, players' performance and season-long success in basketball are particularly based on passing skills.

Hence, studies exploring the basketball pass become essential to improve the training processes and to enhance players' performance and skills, on an individual and collective basis. Considering the complex nature of the pass, studies should involve technical-tactical, physical and mental factors (Passos et al., 2017). In recent years, sports scientists from different areas of knowledge have paid increasing attention to collective behaviour in basketball (Courel-Ibáñez et al., 2017). Although these contributions provided valuable insights into the basketball pass from isolated perspectives, there is an ongoing challenge to design integrative and holistic approaches, combining as many factors as possible to achieve excellence (Schelling and Torres-Ronda, 2016). In this sense, a better understanding and organization of the current literature on the basketball pass is required to determine which factors are most significant for improving training and performance.

Thus, the aim of the current paper was to systematically review and organise the current literature related to the basketball pass to identify

1 - University of Granada, Faculty of Sport Sciences, Department of Physical Education and Sport, Granada, Spain.

2 - University of Murcia, Faculty of Sport Sciences, Department of Physical Education and Sport, Murcia, Spain. 
the most common research topics, the main findings, the shortcomings of the analysis made but, at the same time, the gaps in the specific literature. This information may be of great interest to coaches and instructors, contributing to better characterise the basketball pass processes and subsequent development of training enhancement programs.

\section{Methods}

\section{Literature search}

Systematic review principles were carried out (Moher et al., 2015; Nakagawa and Cuthill, 2007) to conduct a search on the main electronic databases (Web of Science, Scopus, and Sport Discus) using the following keyword combinations: Basketball and pass. The keywords combination was deliberately chosen in order to avoid potential bias, despite the fact that the screening process would last longer. The last search was carried out on January, 2017.

\section{Inclusion and exclusion criteria}

Studies written in Spanish, English, and Portuguese languages were inclusion criteria. Studies had to be published from 2000 onwards, be original as well as peer-reviewed. Exclusion criteria were adapted from Courel-Ibáñez et al. (2017): (a) non-regulated basketball competitions, (b) wheelchair basketball, and (c) included sample matches before 2000. Last exclusion criteria were set up because of the modification of rules (i.e., reducing the time from ten to eight seconds for offensive players to pass the ball into the front court, besides the time reduction to take a shot from thirty to twenty-four seconds). No sample restrictions related to age, sex or category were considered.

\section{Identification and selection of studies}

Figure 1 presents a PRISMA (Preferred Reporting Items for Systematic Reviews and Meta-Analyses) flowchart summarizing the search results. In total, 1402 studies were identified in the original database search from year 2000 onwards (Scopus $=464 ;$ Web of Science $=574 ;$ SportDiscus (full text) $=364$ ). After removing duplicates, the first stage of screening of titles was performed to reduce the amount of studies. Manuscripts not eliminated (257) were subjected to a second-stage screening of articles assessed for eligibility based on inclusion and exclusion criteria (67). At the end of the process a total of 37 studies were included for current systematic review.

\section{Results}

A summary of included studies in the systematic review is provided in Tables 1, 2 and 3 . There has been a significant growth in basketball pass publications in the last years (2010-2017: 26/37, 70.2\%). Overall, this review comprised: 25,458 ball possessions, 843 matches, 1,090 players and 124 coaches/experts. The present review identified five areas of knowledge explored. Studies were summarized and classified accordingly: performance analysis $(\mathrm{n}=16)$, biomechanics $(\mathrm{n}=3)$, physical conditioning $(\mathrm{n}=$ $6)$, mental factors $(n=5)$ and motor skills $(n=12)$. Studies explored three game situations: match $(\mathrm{n}=$ $24)$, analytical situations $(n=7)$ and small sided games $(\mathrm{n}=6)$. The majority of studies explored male samples $(n=21)$ or both sexes $(n=13)$, while only three showed exclusively female results $(\mathrm{n}=$ $3)$. The cohort included seniors $(n=20)$, youths (U18 and $\mathrm{U} 20, \mathrm{n}=7$ ), adolescents (U14 to U16, $\mathrm{n}=$ 8) as well as children (U11 and $U 12, n=2)$.

\section{Discussion}

Analysis of the literature allowed a clear understanding of specific research topics. The present review was based on a total of 37 studies from 2000 to 2017 aimed at investigating the basketball pass. Research was conducted on five main areas of knowledge: performance analysis, motor control, biomechanics, physical conditioning and mental factors. In this article, some gaps in existing knowledge were detected, which might help future research on basketball passing. Studies have been grouped to provide a detailed discussion on key areas, and the main findings were transferred from this scientific knowledge to the practical field. This article may serve as a starting point for future research providing further insights into this research topic. Performance analysis

The findings revealed that passing skills are essential to increase points scored in top level basketball competitions such as the NBA, ACB or Euroleague (Courel-Ibáñez et al., 2016; García et al., 2013; Gómez et al., 2015; Gómez et al., 2016; Marmarinos et al., 2016). These authors have shown particular interest in the role of passing skills in pick and roll situations (Gómez et al., 2013), fast break (Cárdenas et al., 2015), and the 
inside pass (Courel-Ibáñez et al., 2013) to increase the number of assists and the effectiveness of the attack. In addition, players selected passing rather than any other action when they faced increased defensive pressure (Csapo et al., 2015). This supports recommendations on monitoring passing skills during real competitive situations (Sachanidi et al., 2013). In this task, the use of technological resources such as location-based positioning systems (GPS), inertial measurement units, and video track systems, provides a huge amount of data which can be used for training purposes. Likewise, authors highlighted including training tasks such as small sided games (Conte et al., 2016; Iglesias et al., 2003) and decision making drills (Iglesias et al., 2003) to increase the number of passes and decrease the turnovers.

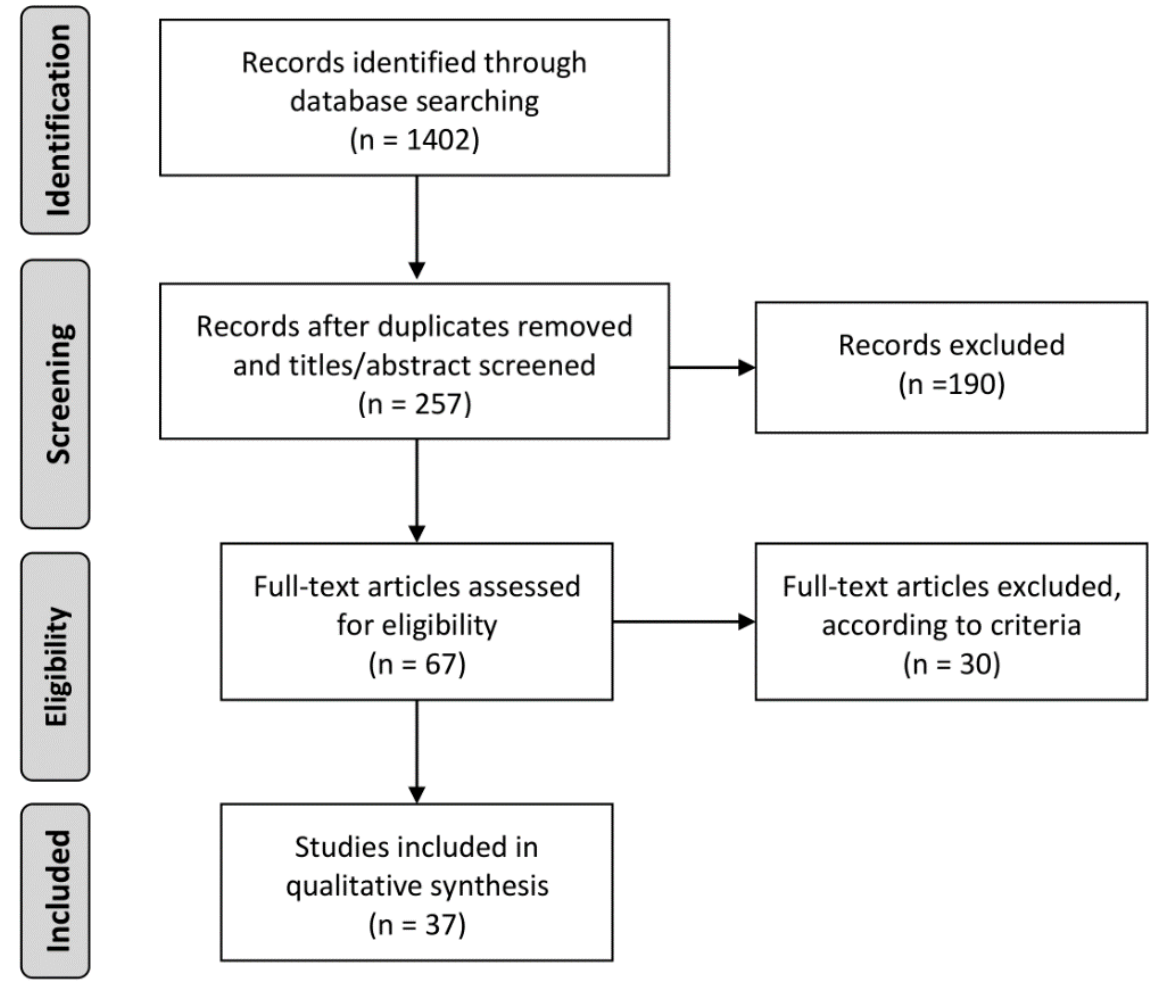

Figure 1

PRISMA flowchart illustrating research at each stage. 
Table 1

Summary of studies exploring the basketball pass (2002 to 2011)

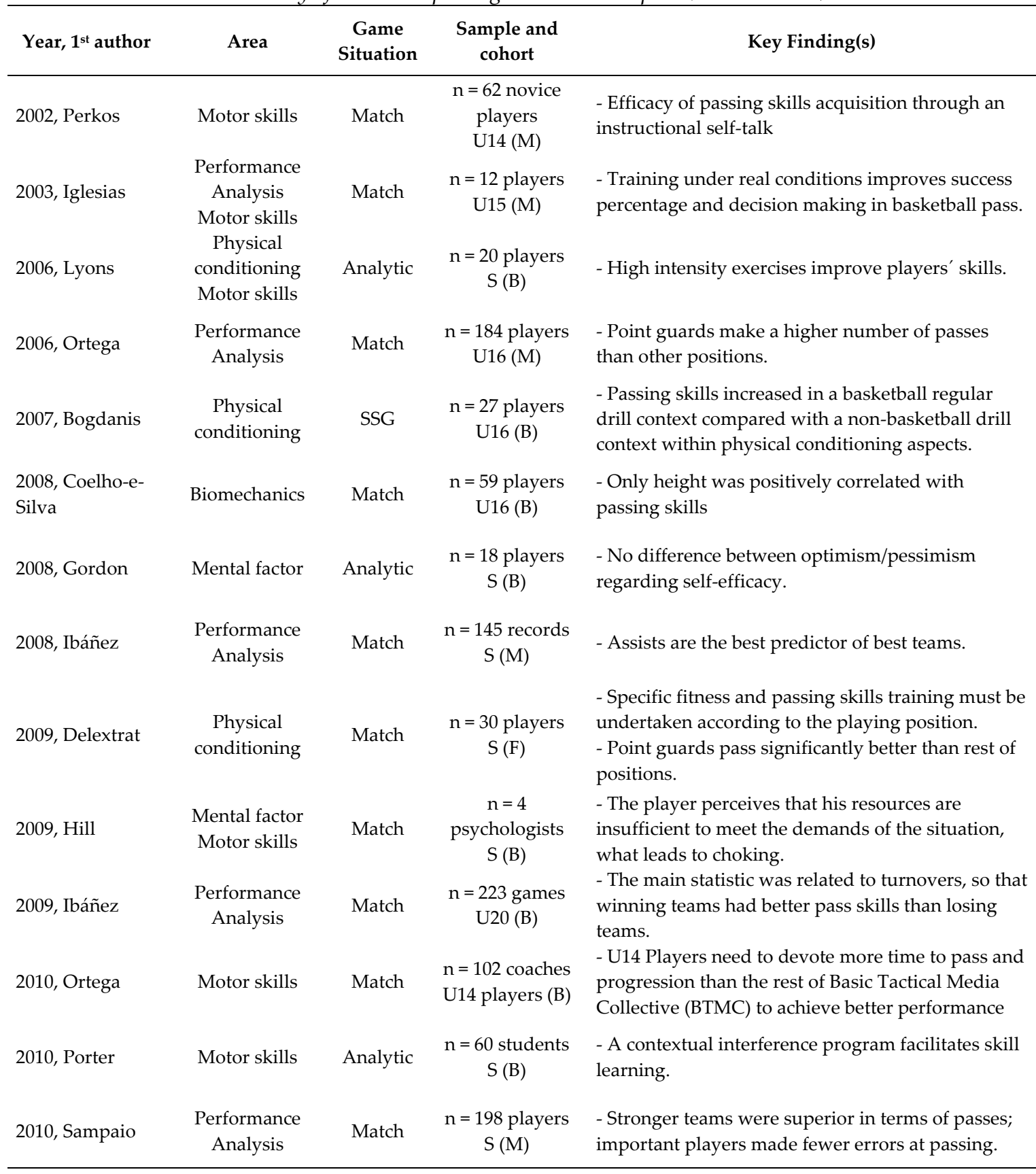

S: Senior, U20: Under 20 years old, U18: Under 18 years old, etc; $M=$ Male, $F=$ Female, $B=B$ Both, Male and Female. 
Table 2

Summary of studies exploring the basketball pass (2012 to 2014)

\begin{tabular}{|c|c|c|c|c|}
\hline Year, $1^{\text {st }}$ author & Area & $\begin{array}{c}\text { Game } \\
\text { Situation }\end{array}$ & $\begin{array}{l}\text { Sample and } \\
\text { cohort }\end{array}$ & Key Finding(s) \\
\hline 2011, Izzo & Biomechanics & Match & $\begin{array}{c}\mathrm{n}=150 \text { games } \\
\mathrm{U} 18(\mathrm{M})\end{array}$ & $\begin{array}{l}\text { - Two handed chest pass is the most used }(39,9 \%) \text {; } \\
\text { one handed bouncing pass }(11,2 \%) \text { is the faster } \\
\text { basketball pass. }\end{array}$ \\
\hline $\begin{array}{l}2012, \\
\text { Afsanepurak }\end{array}$ & $\begin{array}{l}\text { Performance } \\
\text { Analysis } \\
\text { Motor skills }\end{array}$ & Match & $\begin{array}{c}\mathrm{n}=45 \text { players } \\
\mathrm{U} 15(\mathrm{M})\end{array}$ & $\begin{array}{l}\text { - Retention and transfer scores of the groups with } \\
\text { contextual interference were significantly better. }\end{array}$ \\
\hline 2012, Arias & $\begin{array}{l}\text { Performance } \\
\text { Analysis } \\
\text { Motor skills }\end{array}$ & SSG & $\begin{array}{l}\mathrm{n}=54 \text { players } \\
\mathrm{U} 11(\mathrm{M})\end{array}$ & $\begin{array}{l}\text { - Reduction of ball mass ( } 440 \mathrm{~g} \text { ) enabled the } \\
\text { children to go from paying attention to ball to } \\
\text { handling to aspects of game interpretation. }\end{array}$ \\
\hline 2012, Nikolaos & $\begin{array}{l}\text { Physical } \\
\text { conditioning }\end{array}$ & Analytic & $\begin{array}{c}\mathrm{n}=26 \text { players } \\
\mathrm{S}(\mathrm{B})\end{array}$ & $\begin{array}{l}\text { - Improvement in players' passing skills following } \\
\text { the implementation of a balance and } \\
\text { proprioception routine. }\end{array}$ \\
\hline 2012, Shafe & Biomechanics & Match & $\begin{array}{l}\mathrm{n}=3 \text { players } \\
\mathrm{U} 18(\mathrm{M})\end{array}$ & $\begin{array}{l}\text { - Overthrown pass set as the best pass to execute } \\
\text { in a fast break. }\end{array}$ \\
\hline 2013, Ahmed & $\begin{array}{l}\text { Physical } \\
\text { conditioning }\end{array}$ & Analytic & $\begin{array}{c}\mathrm{n}=24 \text { players } \\
\mathrm{U} 18(\mathrm{M})\end{array}$ & $\begin{array}{l}\text { - Passing accuracy decrease when upper fatigue } \\
\text { appears. }\end{array}$ \\
\hline 2013, Conte & Motor skills & SSG & $\begin{array}{c}\mathrm{n}=21 \text { players } \\
\mathrm{U} 11(\mathrm{~B})\end{array}$ & $\begin{array}{l}\text { - Passing skills are better acquired by performing } \\
\text { an understanding education. }\end{array}$ \\
\hline $\begin{array}{l}\text { 2013, Courel- } \\
\text { Ibáñez }\end{array}$ & $\begin{array}{l}\text { Performance } \\
\text { Analysis }\end{array}$ & Match & $\begin{array}{c}\mathrm{n}=1,324 \\
\text { possessions } \\
\mathrm{S}(\mathrm{M})\end{array}$ & $\begin{array}{l}\text { - When inside pass is done, teams achieve a larger } \\
\text { amount of points. } \\
\text { - A passer location and immediate receiver action } \\
\text { determinate a successful inside pass. }\end{array}$ \\
\hline 2013, García & $\begin{array}{l}\text { Performance } \\
\text { Analysis }\end{array}$ & Match & $\begin{array}{c}\mathrm{n}=323 \text { games } \\
\mathrm{S}(\mathrm{M})\end{array}$ & $\begin{array}{l}\text { - Winning teams had a larger number of assists } \\
\text { than losing teams. }\end{array}$ \\
\hline 2013, Gómez & $\begin{array}{l}\text { Performance } \\
\text { Analysis }\end{array}$ & Match & $\begin{array}{l}\mathrm{n}=7,234 \\
\text { possessions } \\
\quad \mathrm{S}(\mathrm{M})\end{array}$ & $\begin{array}{l}\text { - Larger number of passes, is one of the main } \\
\text { performance indicator in predicting effectiveness } \\
\text { in basketball. }\end{array}$ \\
\hline 2013, Sachanidi & Motor skills & Match & $\begin{array}{c}\mathrm{n}=33 \text { players } \\
\mathrm{U} 16(\mathrm{M})\end{array}$ & $\begin{array}{l}\text { - Passing efficiency in games could predict final } \\
\text { performance of the athlete. }\end{array}$ \\
\hline 2014, Tahmasebi & Motor skills & Analytic & $\begin{array}{l}\mathrm{n}=72 \text { students } \\
\mathrm{S}(\mathrm{B})\end{array}$ & $\begin{array}{l}\text { - Motivational self-task helps to improve precision } \\
\text { in passing }\end{array}$ \\
\hline
\end{tabular}

S: Senior, U20: Under 20 years old, U18: Under 18 years old, etc; $M=$ Male, $F=$ Female, $B=$ Both, Male and Female). 
Table 3

Summary of studies exploring the basketball pass (2015 to 2017)

\begin{tabular}{|c|c|c|c|c|}
\hline $\begin{array}{l}\text { Year, } 1^{\text {st }} \\
\text { author }\end{array}$ & Area & $\begin{array}{c}\text { Game } \\
\text { Situation }\end{array}$ & $\begin{array}{l}\text { Sample and } \\
\text { cohort }\end{array}$ & Key Finding(s) \\
\hline $\begin{array}{l}\text { 2015, } \\
\text { Cárdenas }\end{array}$ & $\begin{array}{l}\text { Performance } \\
\text { Analysis }\end{array}$ & Match & $\begin{array}{c}\mathrm{n}=172 \text { fast } \\
\text { breaks } \\
\mathrm{S}(\mathrm{M})\end{array}$ & $\begin{array}{l}\text { - Elite teams usually made maximum two } \\
\text { passes }(96.4 \%) \text {. } \\
\text { - Fast break successfulness increased when } \\
\text { the initial action was a pass. }\end{array}$ \\
\hline 2015, Conte & $\begin{array}{l}\text { Performance } \\
\text { Analysis }\end{array}$ & SSG & $\begin{array}{c}\mathrm{n}=23 \text { players } \\
\mathrm{U} 18(\mathrm{M})\end{array}$ & $\begin{array}{l}\text { - No-dribble-game-drill condition elicited a } \\
\text { greater physiological demand and a higher } \\
\text { number of passes than the regular-drill one. }\end{array}$ \\
\hline 2015, Csapo & $\begin{array}{l}\text { Performance } \\
\text { Analysis }\end{array}$ & Match & $\begin{aligned} \mathrm{n}_{1}= & 18 \text { coaches } \\
\mathrm{n}_{2}= & 20 \text { players } \\
& \mathrm{S}(\mathrm{M})\end{aligned}$ & $\begin{array}{l}\text { - Players selected "pass" regardless of the } \\
\text { previous performance when they faced } \\
\text { increased defensive pressure. }\end{array}$ \\
\hline 2015, Galatti & Mental factor & Match & $\begin{array}{l}\mathrm{n}=7 \text { players } \\
\mathrm{S}(\mathrm{F})\end{array}$ & $\begin{array}{l}\text { - Excellent performance is directly related } \\
\text { with tactic training and group cohesion. }\end{array}$ \\
\hline 2015, Gómez & Mental factor & Match & $\begin{array}{c}\mathrm{n}=147 \text { closed } \\
\text { games } \\
\mathrm{S}(\mathrm{B})\end{array}$ & $\begin{array}{l}\text { - Mental interventions should be } \\
\text { undertaken during the last critical minutes } \\
\text { to avoid negative consequences. }\end{array}$ \\
\hline 2015, Kinrade & Mental factor & SSG & $\begin{array}{c}\mathrm{n}=38 \text { players } \\
\mathrm{S}(\mathrm{M})\end{array}$ & $\begin{array}{l}\text { - Ruminative thoughts lead to worse } \\
\text { performance when making complex } \\
\text { decisions under pressure. }\end{array}$ \\
\hline 2016, Conte & $\begin{array}{l}\text { Performance } \\
\text { Analysis }\end{array}$ & SSG & $\begin{array}{c}\mathrm{n}=21 \text { players } \\
\mathrm{U} 18(\mathrm{~B})\end{array}$ & $\begin{array}{l}\text { - The } 2 \text { vs } 2 \text { condition showed a higher } \\
\text { number of passes and a higher success ratio } \\
\text { than } 4 \text { vs } 4 \text { condition. }\end{array}$ \\
\hline $\begin{array}{l}\text { 2016, Courel- } \\
\text { Ibáñez }\end{array}$ & $\begin{array}{l}\text { Performance } \\
\text { Analysis }\end{array}$ & Match & $\begin{array}{c}\mathrm{n}=4,207 \\
\text { possessions } \\
\mathrm{S}(\mathrm{M})\end{array}$ & $\begin{array}{l}\text { - Attacks including an inside pass were } 1.4 \\
\text { to } 2.0 \text { times more effective. } \\
\text { - A dynamic reception attitude from the } \\
\text { weak side is suggested to enhance scoring } \\
\text { options. }\end{array}$ \\
\hline 2016, Jiménez & Motor skills & Match & $\begin{array}{c}\mathrm{n}=46 \text { players } \\
\mathrm{U} 18(\mathrm{~F})\end{array}$ & $\begin{array}{l}\text { - Results support Contextual Interference } \\
\text { (CI) effect in pass learning skill acquisition }\end{array}$ \\
\hline $\begin{array}{l}\text { 2016, } \\
\text { Marmarinos }\end{array}$ & $\begin{array}{l}\text { Performance } \\
\text { Analysis }\end{array}$ & Match & $\begin{array}{c}\mathrm{n}=12,376 \text { pick } \\
\quad \& \text { rolls } \\
\mathrm{S}(\mathrm{M})\end{array}$ & $\begin{array}{l}\text { - Pick and roll effectiveness could predict } \\
\text { the final score. }\end{array}$ \\
\hline 2017, Quílez & Biomechanics & Analytic & $\begin{array}{c}\mathrm{n}=10 \text { players } \\
\mathrm{S}(\mathrm{M})\end{array}$ & $\begin{array}{l}\text { - Uncertainty increases reaction time in } \\
\text { basketball pass. }\end{array}$ \\
\hline
\end{tabular}

S: Senior, U20: Under 20 years old, U18: Under 18 years old, etc; $M=$ Male, $F=$ Female, $B=$ Both, Male and Female). 


\section{Biomechanics}

Limited research has been conducted focused on biomechanical aspects of the basketball pass. Nonetheless, the results reviewed identified several key points to consider in the success of the pass. Under uncertain conditions, reaction time increased and the accuracy of the pass decreased (Quílez and Rojas, 2017). Thus, exercise variability (i.e., 1 -on-0 including dribbling before passing or 1-on-1 situations with an opponent) should be considered when assessing players' technical passing skills. Izzo and Russo (2011) explored passing techniques among 150 games in the top-level Italian League, NCAA and NBA, concluding that the two-handed chest pass was the most common and easiest, while the one-handed (the second most common) showed the worst effectiveness. In addition, Shafe and Kanon (2012) highlighted the importance of a quick pass, such as with one-hand, in fast-break situations. However, as the increasing speed of the game forces players to solve tasks under limited time constraints, improving the one-hand passing skill stands as a primary training goal in modern basketball (Shafe and Kanon, 2012). Regarding formative stages, Coelho-e-Silva et al. (2008) observed that height may account for better passing skills in U16 players.

Physical conditioning

Authors agreed that optimal conditioning is essential to maintain passing performance during a basketball game (Ahmed, 2013; Bogdanis et al., 2007; Lyons et al., 2006). Ahmed (2013) observed decrements in passing accuracy when the upper extremities were fatigued. Bogdanis et al. (2007) found that decrements on the total oncourt training time resulted in smaller improvement of basketball technical skills. Lyons et al. (2006) suggested high intensity exercises to improve players' passing skills. More specifically, Delextrat and Cohen (2009) suggested that fitness and passing skills training must be undertaken according to specific playing positions. Other authors reported improvements in passing skills following a 12-week intervention of a balance and proprioception routine in amateur basketball players (Nikolaos et al., 2012). However, there is still limited information regarding specific conditioning programs to increase passing performance in basketball.

Mental factors

Most studies were focused on choking episodes, which are defined as a mental disruption in which performance declines during stressful situations, compared with the expected standards (Hill et al., 2009). Gómez et al. (2015) observed that choking situations made players take bad passing decisions, which led to increments in turnovers. In this sense, authors agreed to include pressure and choking situations into regular drills to improve players' performance in real competition (Gordon, 2008; Iglesias et al., 2003; Kinrade et al., 2015). In addition, Kinrade et al. (2015) highlighted the importance of avoiding ruminative thoughts when making complex decisions under pressure. Finally, Galatti et al. (2015) stated that excellent performance was directly related with tactical training and group cohesion. Thus, emotional stability in group drills should be included as another constraint which players have to cope with during the development of passing skills.

Motor skills

The study of passing skills within the motor control paradigm has been mainly focused on contextual interference, which emphasizes the benefits of mixing training items across blocks rather than repeating them (Afsanepurak et al., 2012; Conte et al., 2013; Jiménez et al., 2016; Porter and Magill, 2010; Tahmasebi et al., 2014). The authors underlined the importance of the individual, environment and task constraints that the player had to deal with, to maximize the learning process. Including training drills simulating real situations improved the success rate of the passes and the quality of decisions made (Hill et al., 2009; Iglesias et al., 2003). Small sided games appear to be an effective way to accomplish this objective by increasing the number of passes and reducing the turnovers during practice (Conte et al., 2013). One remarkable point is that practice needs to be adapted to the players' current condition and objective to promote self-task training and learning, which has been proven to be more effective than traditional methodology (Conte et al., 2013; Perkos et al., 2002). Furthermore, training tasks should be new, random and inspiring, to fulfil the contextual interference objectives and promote skill learning (Jiménez et al., 2016). Regarding formative stages, Arias et al. (2012) recommended using a reduced-mass ball (440 g) to facilitate ball handling in U11 players, which increased passes and pass receptions 
compared to the standard ball (485 g). Finally, Ortega (2010) found that coaches agreed on the importance of passing and dive to the rim, from the initial formative stage.

\section{Conclusions}

The present review adds relevant insights into basketball passing skills training, suggesting an integrative approach including biomechanics, performance analysis, physical conditioning, mental factors and motor skills aspects. The summary of existing knowledge regarding these main areas may help coaches and researchers in designing specific training tasks according to players' needs to maximise passing skills development. The assessment of passing skills and performance should be made under uncertain and variable conditions to obtain information on players' responses to competitive scenarios. Small sided games and changing environment stand as the best training situations to improve passing skills. Training sessions should include new and random activities to transfer skills learning to the competition. This review also found it advisable to include training drills under pressure to improve passing skills under competitive conditions similar to the real game. Limited information is available about biomechanical aspects and physical conditioning training plans to improve passing skills in basketball. Likewise, there is scarce data on passing skills development in children. The current review may be of great interest for coaches, contributing to better characterise the basketball pass and subsequent development of training enhancement programs.

\section{References}

Afsanepurak SA, Karimiyani N, Moradi J, Safaei M, Education P, Branch G. The effect of blocked, random, and systematically increasing practice on learning of different types of basketball passes. Euro J Exp Bio, 2012; 2: 2397-2402

Ahmed T. The effect of upper extremity fatigue on grip strength and passing accuracy in junior basketball players. J Hum Kinet, 2013; 37: 71-79

Arias JL, Argudo FM, Alonso JI. Effect of ball mass on dribble, pass, and pass reception in 9-11-year-old boys' basketball. Res Q Exerc Sport, 2012; 83: 407-412

Bogdanis GC, Ziagos V, Anastasiadis M, Maridaki M. Effects of two different short-term training programs on the physical and technical abilities of adolescent basketball players. J Sci Med Sport, 2007; 10: 79-88

Cárdenas D, Ortega E, Llorca J, Courel J, Sánchez-Delgado G, Piñar MI. Motor characteristics of fast break in high level basketball. Kinesiology, 2015; 47: 208-214

Coelho-e-Silva MJ, Figueiredo AJ, Moreira-Carvalho H, Malina RM. Functional capacities and sport-specific skills of 14- to 15-year-old male basketball players: Size and maturity effects. Eur J Sport Sci, 2008; 8: 277-285

Conte D, Favero TG, Niederhausen M, Capranica L, Tessitore A. Physiological and technical demands of no dribble game drill in young basketball players. J Strength Cond Res, 2015; 29: 3375-3379

Conte D, Favero TG, Niederhausen M, Capranica L, Tessitore A. Effect of different number of players and training regimes on physiological and technical demands of ball-drills in basketball. J Sports Sci, 2016; 34: 780-786

Conte L, Moreno-Murcia JA, Perez G, Iglesias, D. Comparison of traditional and understanding methodology in the practice of basketball. Rev Int Med Cienc Ac, 2013; 13: 506-523

Courel-Ibáñez J, McRobert AP, Ortega E, Cárdenas D. Collective behaviour in basketball: a systematic review. Int J Perform Anal Sport, 2017; 17: 44-64

Courel-Ibáñez J, McRobert AP, Ortega E, Cárdenas D. Inside pass predicts ball possession effectiveness in NBA basketball. Int J Perform Anal Sport, 2016; 16: 711-725

Courel-Ibáñez J, Suárez E, Ortega E, Piñar M, Cárdenas D. Is the inside pass a performance indicator? Observational analysis of elite basketball teams. Rev Psicol Deporte, 2013; 22: 191-194

Csapo P, Avugos S, Raab M, Bar-Eli M. How should "hot" players in basketball be defended? The use of fast-and-frugal heuristics by basketball coaches and players in response to streakiness. J Sports Sci, 2015; 33: 1580-1588 
Delextrat A, Cohen D. Strength, power, speed, and agility of women basketball players according to playing position. J Strength Cond Res, 2009; 23: 1974-1981

Galatti LR, Paes RR, Machado GV, Seoane AM. Basketball world champions: determinant factor for excellence performance. Cuad Psicol Deporte, 2015; 15: 187-192

García J, Ibánez SJ, De Santos RM, Leite N, Sampaio JE. Identifying basketball performance indicators in regular season and playoff games. J Hum Kinet, 2013; 36: 161-168

Gómez MA, Gasperi L, Lupo C. Performance analysis of game dynamics during the 4th game quarter of NBA close games. Int J Perform Anal Sport, 2016; 16; 249-263

Gomez MA, Lorenzo A, Ibanez SJ, Sampaio J. Ball possession effectiveness in men's and women's elite basketball according to situational variables in different game periods. J Sports Sci, 2013; 31: 1578-1587

Gómez MA, Lorenzo A, Jiménez S, Navarro RM, Sampaio J. Examining choking in basketball: effects of game outcome and situational variables during last 5 minutes and overtimes. Percept Mot Skills, 2015; 120: 111-24

Gómez MA, Lorenzo A, Ortega E, Sampaio J, Ibáñez SJ. Game related statistics discriminating between starters and nonstarters players in Women's National Basketball Association League (WNBA). J Sports Sci Med, 2009; 8: 278-283

Gómez MA, Prieto M, Pérez J, Sampaio J. Ball possession effectiveness in men's elite floorball according to quality of opposition and game period. J Hum Kinet, 2013; 38: 227-237

Gordon RA. Attributional style and athletic performance: Strategic optimism and defensive pessimism. J Sport Exerc Phsychol, 2008; 9: 336-350

Hill DM, Hanton S, Fleming S, Matthews N. A re-examination of choking in sport. Eur J Sport Sci, 2009; 9: 203-212

Ibáñez SJ, García J, Feu S, Lorenzo A, Sampaio J. Effects of consecutive basketball games on the game-related statistics that discriminate winner and losing teams. J Sports Sci Med, 2009; 8: 458-462

Ibáñez SJ, Sampaio J, Feu S, Lorenzo A, Gómez MA, Ortega E. Basketball game-related statistics that discriminate between teams' season-long success. Eur J Sport Sci, 2008; 8: 369-372

Iglesias D, Fuentes J, Moreno A, Del Villar F. The improvement of the decision making in the basketball pass through a program oriented to the acquisition of knowledge. In CIB 2003. II Congreso Iberoaméricano de Baloncesto. Cáceres: Universidad de Extremadura

Izzo RE, Russo L. Analysis of Biomechanical Structure and Passing Techniques in Basketball. TPERJ, 2011; 3: $41-46$

Jiménez J, Salazar W, Morera M. Contextual interference in motor skills performance: a meta-analysis review. PensarMov, 2016; 14: 1-34

Kinrade NP, Jackson RC, Ashford KJ. Reinvestment, task complexity and decision making under pressure inbasketball. J Sport Exerc Phsychol, 2015; 20: 11-19

Lyons M, Al-Nakeeb Y, Nevill AM. The impact of moderate and high intensity total body fatigue on passing accuracy in expert and novice basketball players. J Sports Sci Med, 2006; 5: 215-227

Marmarinos C, Apostolidis N, Kostopoulos N, Apostolidis A. Efficacy of the "pick and roll" offense in top level European basketball teams. J Hum Kinet, 2016; 50: 121-129

Matthews M, O'Conchuir C, Comfort P. Acute effect of alternating heavy and light resistances on power output during upper-body complex power training. J Strength Cond Res, 2009; 23: 1988-1995

Moher D, Shamseer L, Clarke M, Ghersi D, Liberati A, Petticrew M, Stewart LA. Preferred reporting items for systematic review and meta-analysis protocols (PRISMA-P) 2015 statement. Syst Rev, 2015; 4: 1-25

Nakagawa S, Cuthill IC. Effect size, confidence interval and statistical significance: A practical guide for biologists. Biol Rev, 2007; 82: 591-605

Nunes H, Iglesias X, Daza G, Irurtia A, Caparrós T, Anguera MT. The influence of pick and roll in attacking play in top-level basketball. Cuad Psicol Deporte, 2016; 16: 129-142

Nikolaos K, Evangelos B, Nikolaos A, Emmanouil K, Panagiotis K. The effect of a balance and proprioception training program on amateur basketball players' passing skills. J Phys Educ Sport, 2010; 12: $316-323$

Ortega E. Tactical media collective in basketball in youth categories. RICYDE, 2010; 10: 234-244

Ortega E, Cárdenas D, Sainz De Baranda P, Palao JM. Analysis of the final actions used in basketball during formative years according to player's position. J Hum Movement Stud, 2006; 50: 421-437 
Passos P, Araújo D, Volossovitch A. Performance analysis in team sports. New York: Routledge; 2017

Perkos S, Theodorakis Y, Chroni S. Enhancing performance and skill acquisition in novice basketball players with instructional self-talk. Sport Psychol, 2002; 16: 368-383

Porter JM, Magill RA. Systematically increasing contextual interference is beneficial for learning sport skills. J Sports Sci, 2010; 28: 1277-1285

Quílez A, Rojas FJ. Assessment of the point of no return in choice reaction time under uncertainty conditions in basketball pass. SPORT TK Rev. Euroam. Cienc. Deporte, 2017; 6: 213-220

Ribeiro C, Sampaio J. Analysis of the last 5 minutes of balanced basketball games. In Actas del I congreso Ibérico de Baloncesto (pp. 13-22). Cáceres: Universidad de Extremadura; 2001

Sachanidi M, Apostolidis N, Chatzicharistos D, Bolatoglou T. Passing efficacy of young basketball players: test or observation? Int J Perform Anal Sport, 2013; 13: 403-412

Sampaio J, Drinkwater EJ, Leite NM. Effects of season period, team quality, and playing time on basketball players' game-related statistics. Eur J Sport Sci, 2010; 10: 141-149

Schelling X, Torres-Ronda L. An Integrative Approach to Strength and Neuromuscular Power Training for Basketball. Strength Cond J, 2016; 38: 72-80

Shafe KA, Kanon MA. A biomechanical study to assist pass in fast break for the senior basketball. World $J$ Sport Sci, 2012; 7: 164-172

Tahmasebi S, Nikos Z, Shahbazi M. The effects of instructional and motivational self-talk on basketball passing and shooting performance in novice students. Med Sport, 2014; 67: 397-410

\section{Corresponding author:}

\section{Arturo Quilez Maimón}

University of Granada, Faculty of Sport Sciences

Carretera de Alfacar, s/n, 18011, Granada, Spain

Phone number: (+34) 648209692,

E-mail: arturoquilez@gmail.com 